\title{
Analysis of the lympho-plasmacytic infiltrate in Crohn's disease with special reference to identification of lymphocyte-subpopulations ${ }^{1}$
}

\author{
S. G. M. MEUWISSEN ${ }^{2}$, THEA M. FELTKAMP-VROOM, A.BRUTEL DE LA \\ RIVIERE, A. E. G. KR. VON DEM BORNE, AND G. N. TYTGAT
}

From the Central Laboratory of the Netherlands Red Cross Blood Transfusion Service, Amsterdam, the Laboratory for Experimental and Clinical Immunology, and the Division of Gastroenterology, University of Amsterdam, the Netherlands

SUMMARY Lympho-plasmacytic infiltrates in cryostat sections (resected small intestine or colon specimens and rectal biopsies) from 29 patients with Crohn's disease (CD) were studied with the immunoperoxidase and immunofluorescence technique, by means of specific anti-human lymphocyte globulin (ALG) and specific anti-human T-lymphocyte globulin (ATG). Control specimens were obtained from 16 patients with ulcerative colitis (UC) and 12 subjects without inflammatory bowel disease. Characteristic transmural inflammatory infiltrates in CD consisted mainly of lymphocytes. A wide variation of the relative T-cell proportion was observed. However, in contrast with UC, abundant numbers of T-lymphocytes in CD were often detected, particularly in the deeper layers of the bowel wall. Furthermore, in serial sections immunoglobulin-containing plasma cells were counted, using specific anti-IgA, -IgM, and -IgG antisera. A significant reduction of the $\operatorname{IgA} / \operatorname{IgM}$ plasma cell-ratio was found in CD in comparison with UC and controls. Our results indicate that in CD a chronic cellular immune reaction is going on within the diseased gut, involving increased numbers of lymphocytes and particularly $\mathrm{T}$-cells. It remains to be established whether a deficient IgA barrier has to be considered of primary pathogenetic importance.

Hyporesponsiveness of the cell-mediated immune system in patients with Crohn's disease (CD) has been reported by many authors (Williams et al., 1965; Jones et al., 1969; Parent et al., 1971; Guillou et al., 1973; Sachar et al., 1973; Richens et al., 1974; Meuwissen et al., 1975). However, it is not established to what extent impaired cellular immunity can be explained by a shift of thymus-derived (T) lymphocytes towards the diseased gut. Recently, the

'Presented in part at the 'Workshop on Crohn's disease', Leyden, October 1975, and also at the Annual Meeting of the American Gastroenterological Association, Miami, May 1976.

Address for reprint requests: Dr S. G. M. Meuwissen, Division of Gastroenterology, Wilhelmina Gasthuis and Binnengasthuis, le Helmersstraat 104, Amsterdam, the Netherlands.

Received for publication 10 June 1976 presence of increased numbers of both T- and B (bursa-equivalent) lymphocytes in tissue sections of two CD patients has been reported by Strickland et al. (1975). To our knowledge, no other detailed studies have been published characterising the typical transmural lymphoplasmacytic infiltrates in CD.

We therefore studied multiple tissue sections from a large group of patients with $\mathrm{CD}$, ulcerative colitis (UC), and control subjects by means of an antiserum, specific for blood lymphocytes, detecting $\mathrm{T}$ and non-T lymphocytes, as well as by means of an antiserum, specific for T-lymphocytes only.

Attention was also paid to the number of immunoglobulin-containing plasma cells within the lamina propria, because reduction of IgA-containing plasma cells and deficient local IgA synthesis in CD could explain an increased entry of antigenic substances, as recently suggested by Green and Fox (1975). 


\section{Methods}

\section{SUBJECTS}

Twenty-nine CD patients (mean age 28.9 years, range 14-49 years, 14 females and 15 males) were studied. The disease was confined to the terminal ileum in nine, ileocolitis was diagnosed in eight, and the diagnosis Crohn's disease of the colon was established in 12, according to criteria described elsewhere (Meuwissen et al., 1976a). Sixteen UC patients were also studied (mean age 38.3 years, range 14-66 years, 12 females and four males). Finally, 12 patients not suffering from inflammatory bowel disease served as controls. Normal tissue sections from the latter group were obtained at routine sigmoidoscopy for other diseases, particularly malignancy of the gastrointestinal tract, or obtained at surgery (colon carcinoma, or colon diverticulosis). Nine CD patients and four UC patients received corticosteroids and/or azathioprine, at the time of the biopsy. The large majority of both groups with inflammatory bowel disease was treated with azulfidine.

\section{SPECIMENS}

Transmural specimens, $3 / 4 \times 3 / 4 \mathrm{~cm}$, obtained at surgery from ileum or colon, were immediately deepfrozen in liquid nitrogen and stored at $-196^{\circ} \mathrm{C}$, until used, as described by Feltkamp-Vroom and Boode (1970). The numbers of blocks removed at surgery per patient varied from two to eight, with an average of four. Particular attention was paid to select areas of non-ulcerated, oedematous, often nodular mucosa, surrounded by characteristic ulcerative lesions. In a few patients enlarged mesenteric lymph nodes were also studied. Rectal biopsy specimens were taken from the posterior rectal wall, 8-10 $\mathrm{cm}$ from the anal margin or from well-defined pathological areas, orientated, and enclosed in gelatin capsules and deep-frozen, as described above.

\section{LIGHT MICROSCOPY}

For routine diagnostic purposes formalin fixed tissue specimens were available from representative areas and stained with haematoxylin and eosin (HE). In addition, cryostat sections of frozen biopsies, adjacent to the ones used for incubation with ATG and ALG, were also stained with $\mathrm{HE}$. Sections were analysed, paying attention to the following criteria: epitheloid cell granulomata with or without multinucleated giant cells, areas of extensive submucosal or transmural inflammation, disproportionate and discontinuous character of the inflammatory infiltrate (Morson and Dawson, 1972), presence of well-defined lymphoid follicles, cryptitis, cryptabscess formation, intact or decreased goblet cell number, and mucus content. According to these criteria, sections were considered as showing specific histological features, suggestive for $\mathrm{CD}$, or nonspecific abnormalities, or as being within normal limits. In UC a diagnosis was made of active, or chronic non-active disease, according to Whitehead (1973).

\section{ANTISERA}

Specific anti-lymphocyte globulin ( $A L G)$

Rabbits were immunised against isolated normal human peripheral blood lymphocytes. The resulting antiserum was not spontaneously specific for lymphocytes. Therefore, repeated absorptions of the antiserum were performed with human red blood cells, made leucocyte free by filtration, isolated human granulocytes, and platelets. The antiserum was tested by the indirect immunofluorescence technique (IFT) on isolated human blood cells in suspension as well as in smears (lymphocytes, granulocytes, monocytes, platelets, T-lymphocytes, and chronic lymphatic leukaemia (CLL) cells). Moreover, its reactivity with various plasma proteins was established with a passive agglutination test. After the above absorptions, the serum proved to react only with lymphocytes, T-lymphocytes, and CLL cells. In tissue sections the antiserum therefore recognises $\mathrm{T}$ - and non- $\mathrm{T}$ lymphocytes, but not pyroninophilic germinal centre cells (GC cells), or mature plasma cells.

\section{Specific anti-T lymphocyte globulin $(A T G)$}

Rabbits were immunised with human T-lymphocytes, obtained at cardiac surgery from thymus tissue of small children. The resulting antiserum which was not spontaneously specific for T-lymphocytes, was repeatedly absorbed with leucocyte free human red cells, isolated human granulocytes, and CLL cells from different donors. The specificity after absorption was established, as described above. In addition, lymphocyte suspensions, depleted or enriched in T-cells, were also studied. According to the specificity criteria, proposed by the WHO/IARC workshop (1974), the preparation is considered specific for T-lymphocytes in the indirect IFT. Elaborate details about preparation and specificity testing of the ALG and ATG will be described elsewhere (Brutel de la Rivière et al., 1976a, b). Before use in the indirect IFT, both ALG and ATG were absorbed with acetone dried human liver powder, $10 \mathrm{mg} / 1 \mathrm{mg}$ (Coons et al., 1955).

\section{Fluorescein-labelled antisera}

Specific antisera against human $\operatorname{IgA}, \operatorname{IgM}$, and $\operatorname{IgG}$, labelled with fluorescein isothiocyanate (FITC) and FITC labelled swine anti-rabbit IgG (SwaR-FITC) 
were purchased from Dakopatts, Denmark. The results with the commercially obtained anti-IgG antiserum were compared in the initial part of the study with the FITC labelled anti-IgG antiserum prepared at the Central Laboratory. No obvious differences were noticed and therefore only one anti-IgG antiserum (Dakopatts) was selected for further use. Tetramethylrhodamine isothiocyanate labelled horse anti-rabbit Ig (HoaR-TRITC) was prepared at the Central Laboratory.

IMMUNOFLUORESCENCE TECHNIQUE (IFT)

Four micron thick serial sections were cut in an open cryostat at $-20^{\circ} \mathrm{C}$, air-dried, fixed in acetone for 10 minutes, washed in phosphate buffered saline, $\mathrm{pH}$ 7.4 (PBS) for 30 minutes and stained. The incubation time in the indirect IFT (ATG, dilution 1:20 and ALG, dilution $1: 40$ ), was 30 minutes, followed by washing in PBS for 30 minutes and a further incubation for 30 minutes with the SwaR-FITC, diluted $1: 120$, followed by a final washing for 30 minutes. In some patients double-staining procedures were also carried out, to detect $\mathrm{T}$ - as well as non-T lymphocytes in the same section: staining first with ATG and SwaR-FITC to detect T-cells, thereafter incubating with ALG and HoaR-TRITC as a fourth layer. The detailed procedure of these double staining techniques will be described elsewhere (Schoorl et al., 1976). The incubation time in the direct IFT with FITC-labelled anti-immunoglobulin antisera was 60 minutes.

IMMUNOPEROXIDASE TECHNIQUE (IPT)

In a large number of pilot experiments, the indirect IFT was used to study the distribution of T-lymphocytes. However, for the quantitative assessment, the IPT was preferred as a more convenient method, because slides can be stored permanently and examined by routine light microscopy. Serial sections of biopsies from all patients were incubated with both ATG or ALG, followed by incubation for one hour with 1:160 diluted peroxidase labelled horse anti-rabbit IgG (prepared at the Central Laboratory, according to Avrameas and Ternynck, 1971). After washing with PBS for 30 minutes, sections were

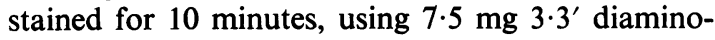
benzidine tetrahydrochloride (DAB), in $10 \mathrm{ml}$ PBS, containing $0.01 \%$ freshly prepared hydrogen peroxide. After washing in PBS, sections were postfixed for $\mathbf{3 0}$ seconds with $1 \%$ osmium tetroxide, dehydrated and mounted.

\section{FLUORESCENCE MICROSCOPY}

Fluorescence microscopy was performed with a Leitz Orthoplan fluorescence microscope, equipped with incident illumination (filter combinations no. 3 and 4
Ploem Opak). For excitation a mercury lamp (Philips CS $150 \mathrm{~W}$ ) was used. All fluorescence sections were read within 24 hours after incubation. Fluorescence photographs were taken with a Leitz Orthomat camera, using Ansco 200 and Kodak Tri X Pan. Micrographs of the peroxidase stained sections were made with Kodak Panatomic-X. The number of cells with cytoplasmic fluorescence for IgA, IgM, and IgG (plasma cells) within the lamina propria were counted by means of an eyepiece grid, the unit area of the lamina propria at the chosen magnification (objective $25 \mathrm{x}$ ), being $0.0748 \mathrm{~mm}^{2}$. No correction was made for the area occupied by epithelial tissue. In each slide at least 10 fields (non-ulcerated areas) were counted and in case of non-homogeneous plasmacyte distribution 20 fields. In all surgical specimens at least two to three sections from different areas were examined, and averaged, after conversion to logarithmic values. Counting was performed by one investigator, without prior knowledge of the diagnosis or antiserum used. However, regularly duplicate counts were also performed by a second investigator, without obvious differences.

\section{Quantitation of T-cell infiltration}

Cell counting by means of a grid is only meaningful in case of homogeneous cell distribution. This accurate method therefore cannot be applied to the quantitation of focal transmural lymphocyte clusters and we had to rely on a semi-quantitative method. The following score was used: grade 0 : no $\mathrm{T}$ lymphocytes; grade 1: very few T-lymphocytes; grade 2: moderate number of T-lymphocytes; grade 3: many T-lymphocytes present; grade 4: abundant numbers of T-lymphocytes. This score was applied separately to lamina propria, submucosa, muscularis propria, and subserosal layer. All sections were scored by two independent investigators, without prior knowledge of the diagnosis.

\section{Non-specific esterase}

To identify macrophages within granulomata, cryostat sections were stained for non-specific esterase, according to Yam et al. (1971).

\section{Statistics}

For statistical analysis, cell numbers of both small intestine and colon were pooled, because, as shown by Green and Fox (1975), no topical differences were to be expected. No distinction was made between biopsies of patients, with or without immunosuppressive therapy, because only a limited number of patients has been treated with corticosteroids and/or azathioprine. Moreover differences, if any, were of insufficient degree to be detected on pilot screening. Differences of the ratio of $\operatorname{IgA} / \operatorname{IgM}$ - and $\operatorname{IgA} / \operatorname{IgG}$ 


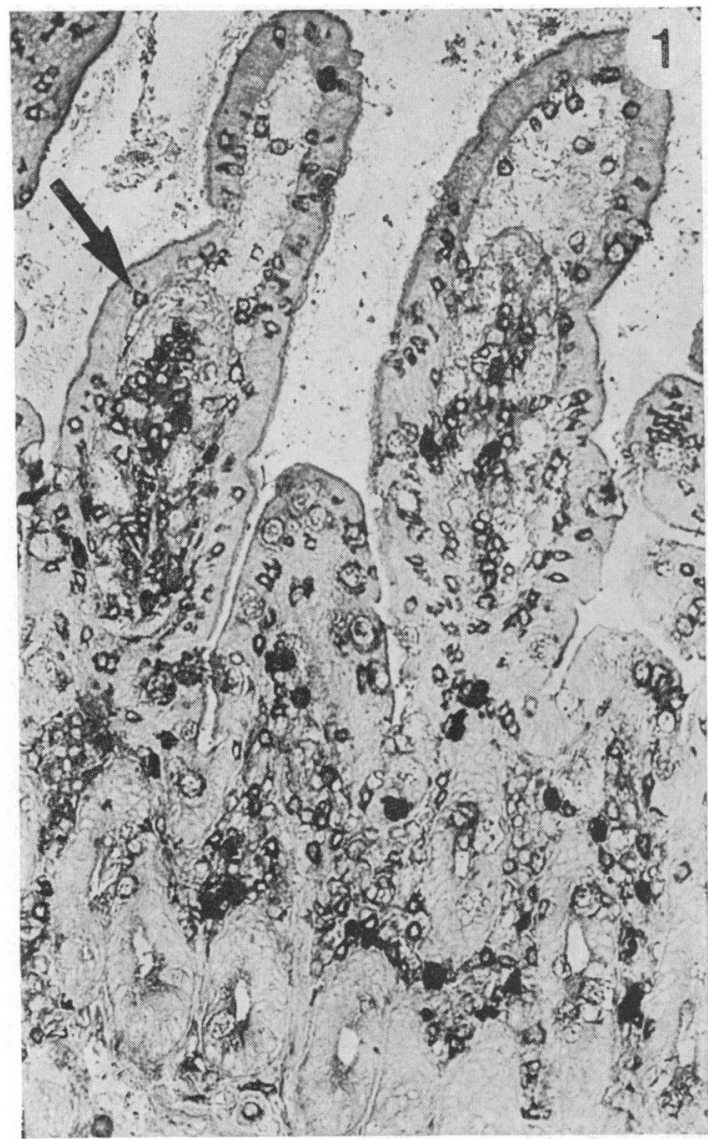

Fig. 1 Distribution of T-lymphocytes in normal small intestinal tissue. Note the intra-epithelial T-lymphocytes (arrow). The dark staining cells are granulocytes and/or macrophages, with spontaneous peroxidase activity. Immunoperoxidase technique $=I P T, x \pm 150$.

containing plasma cells, counted in serial sections, were analysed by means of Student's $t$ test, after conversion of individual points to logarithmic values. Analysis of the differences of the absolute plasma cell numbers was not considered to be meaningful, because no correction has been made for the area, occupied by epithelial tissue.

\section{Results}

\section{LYMPHOCYTE DISTRIBUTION}

\section{Normal tissue}

Using ALG, scattered lymphocytes were found in the lamina propria of normal ileum or colon. The majority of these cells were identified as T-cells,
T-cell distribution is shown in Fig. 1. The large majority of intraepithelial lymphocytes were also Tcells, as confirmed by the double-staining procedure. The deeper layers of normal intestine were strikingly devoid of lymphocytes and only occasionally a Tcell was seen. In a few sections, particularly of rectal biopsies, small lymphoid follicles were detected superficially in the submucosa, mainly consisting of non-T cells in the centre, surrounded by small numbers of T-lymphocytes.

\section{Crohn's disease}

A lymphoid follicle in a mesenteric gland of a CD patient is illustrated in Fig. 2. A few T-cells were often observed, within the germinal centre, scattered between the GC cells, and also between the GC and the marginal zone, the latter consisting mainly of non-T lymphocytes. Around the marginal zone small clusters of T-cells were also found. In Fig. 3 a lymphoid follicle is illustrated, incubated with ALG. Almost all marginal zone cells were positive, whereas the GC-cells stained negative. Although only a limited number of lymph nodes of CD patients have been studied, it was obvious that the paracortical areas, particularly in hyperplastic glands, contained abundant numbers of T-lymphocytes, as was to be expected.

Small intestinal- and colonic tissue of CD patients showed a striking variability of lymphocyte distribution. In apparently normal areas, or in sections showing only mild inflammation, no conspicuous differences were noticed in comparison with control tissue. The intact mucosa contained as a rule normal or only slightly increased T-cell numbers. The number of intraepithelial T-cells was not obviously different in sections with typical CD pathology, compared with apparently normal areas. Sometimes, small clusters of lymphocytes were found within the lamina propria, composed of T-cells (Fig. 4). In contrast, when heavy lymphocytic infiltration of the mucosal layer occurred, mainly non-T cells $( \pm 70-80 \%)$ were observed.

Well-developed, normally structured lymphoid follicles in the submucosa contained as a rule only a minority of T-cells. Instead, extensive submucosal inflammatory infiltrates, often surrounding lymphoid follicles, contained abundant numbers of $\mathrm{T}$ cells $(50.90 \%$ ), as shown in Figs. 5, 6, and 7. Small submucosal lymphocyte clusters contained also a high number of T-cells, as shown in Fig. 8. In areas of more or less deep ulceration, only limited numbers of T-cells were found, the majority of lymphocytes being non-T cells (Fig. 9). The muscle layer usually contained a small number of lymphocytes, mainly T-cells. Occasionally, however, obviously increased numbers of T-cells were found, infiltrating between the muscle fibres (Figs. 10 and 11), and T-cell collec- 


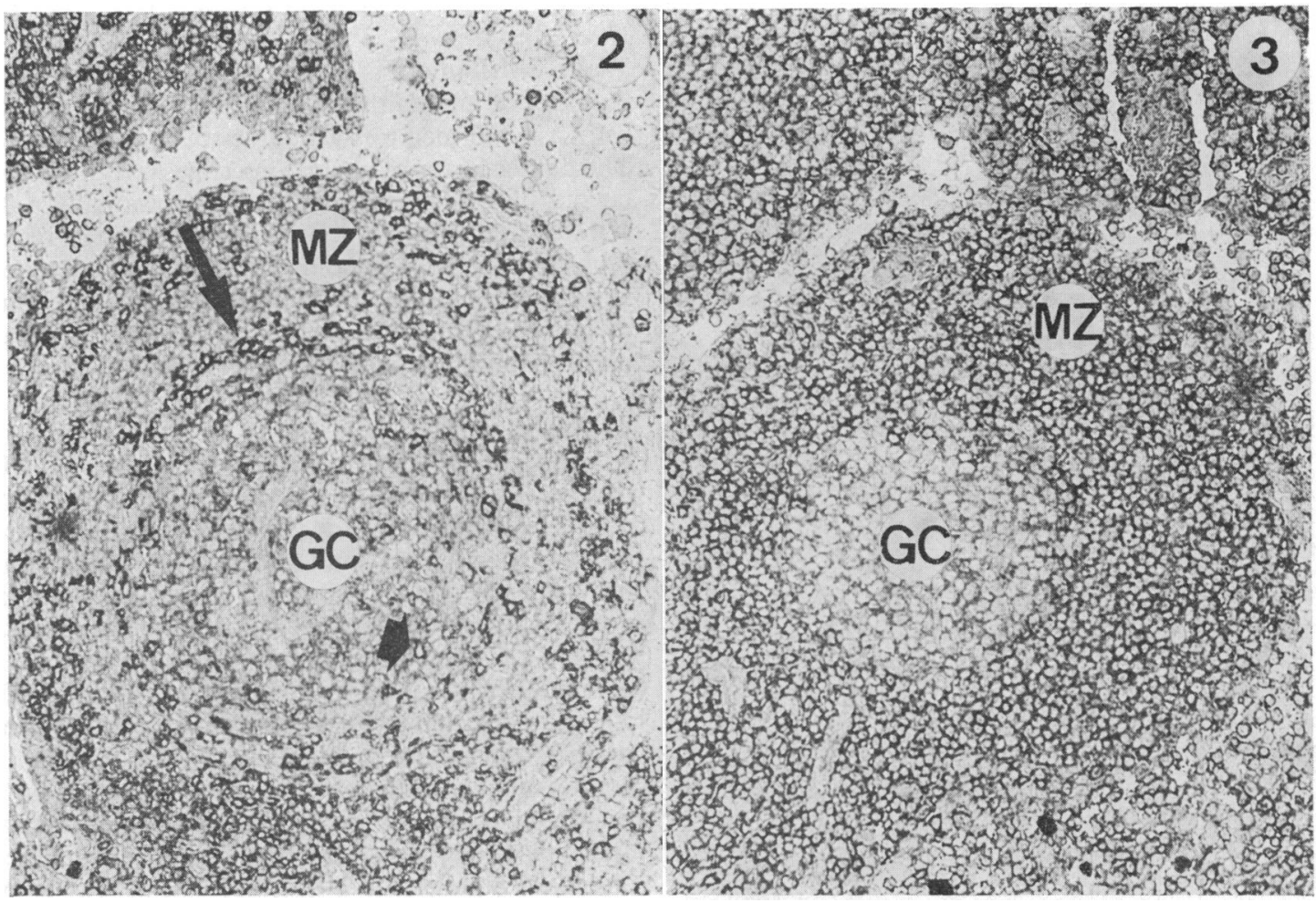

Fig. 2 Lymph node follicle, of a CD patient, incubated with ATG. The germinal centre is almost negative, with a few T-lymphocytes scattered in between (small arrow). Between the GC and the marginal zone (MZ) a small number of T-positive cells is found (large arrow). The marginal zone does not contain more than an occasional T-cell:

however at the periphery, again a substantial number of T-cells is seen. IPT, $\times \pm 150$.

Fig. 3 Lymph node follicle, incubated with ALG. The GC cells are negative. In contrast with Fig. 2, almost every lymphocyte in the marginal zone stains positively. Original magnification, IPT, $\times \pm 150$.

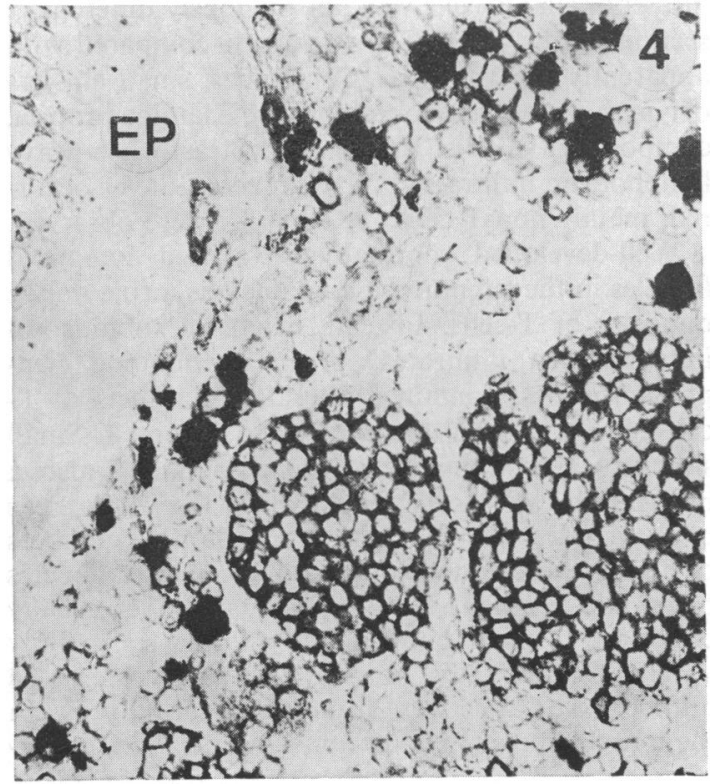

Fig. 4 Small, well-defined lymphocyte clusters, consisting mainly of T-cells, within the lamina propria of a $C D$ patient. $E P=$ epithelium. IPT,$\times \pm 400$. 


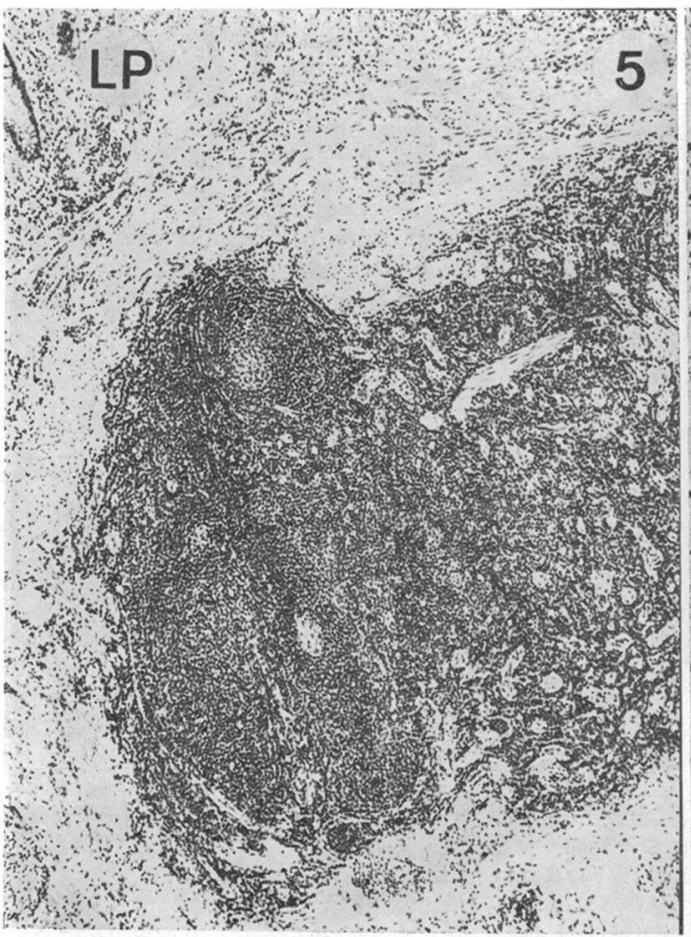

Fig. 5 Low power magnification of a characteristic submucosal infiltrate in $C D . L P=$ lamina propria. $H$ and $E$ staining, $\times \pm 50$.

Fig. 6 Serial section of infiltrate of Fig. 5, incubated with ATG. There are abundant numbers of T-lymphocytes, surrounding two lymphoid follicles. The window refers to the detailed photograph of Fig. 7. IPT, $\times \pm 50$.

Fig. 7 Detail of Fig. 6. A clearly visible lymphoid follicle, T-cell negative, is shown, with a small GC and also a few T-cells within the GC. IPT, $\times \pm 150$.

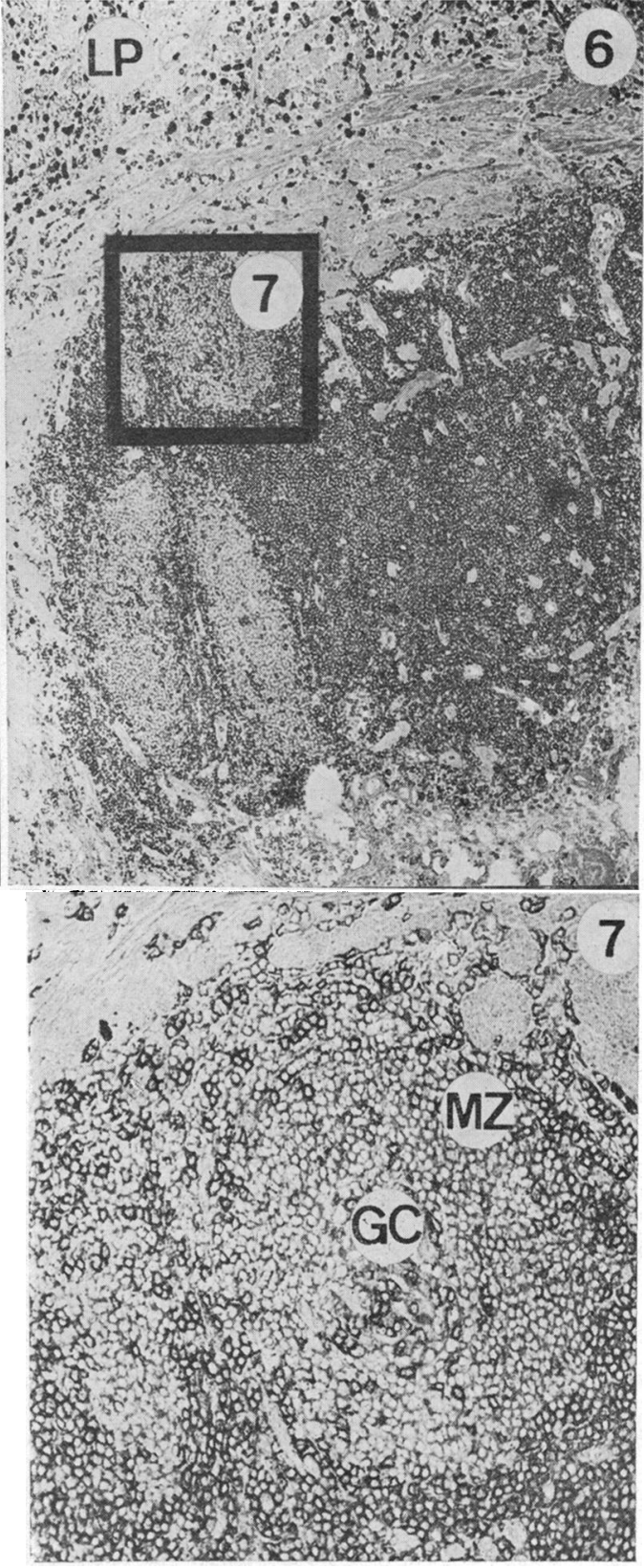

cytic cells, staining strongly positive for non-specific csterase. They were mainly surrounded by lymphocytes, particularly T-cells, and occasionally T-cells were also present within the granuloma. Sections, containing granulomata, were also incubated with FITC-labelled anti-IgA, -IgM, and -IgG antiserum. tions were also regularly seen in the subserosal area in contrast with UC and control tissue.

In five sections epitheloid cell granulomata, with or without giant cells, were detected in the submucosa or in the deeper layers, as illustrated in Fig. 12. These granulomata contained collections of histio- 


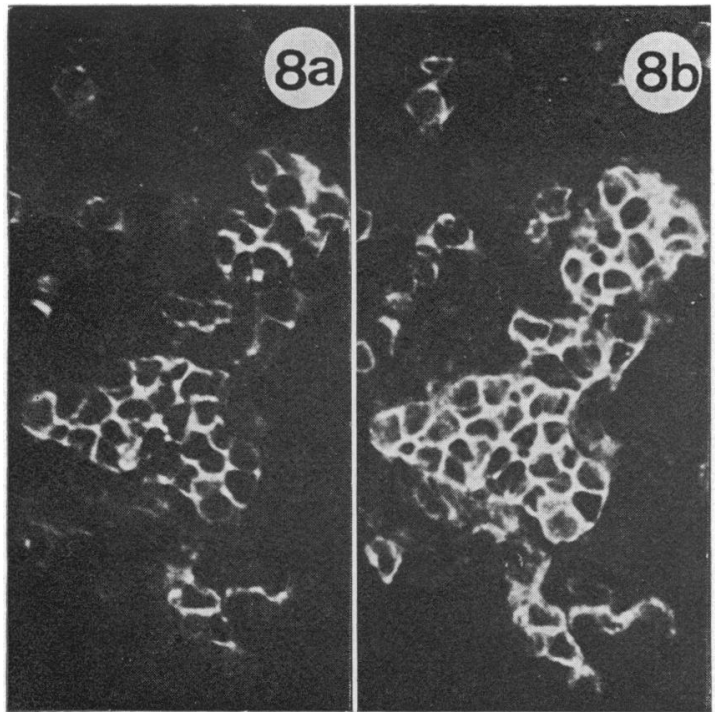

Fig. 8 Submucosal cluster of lymphocytes in $C D$ (IFT, double staining procedure, with $A T G, 8 a$, and $A L G, 8 b)$. Note that the large majority of cells stains with both antisera. IFT, $\times \pm 500$.

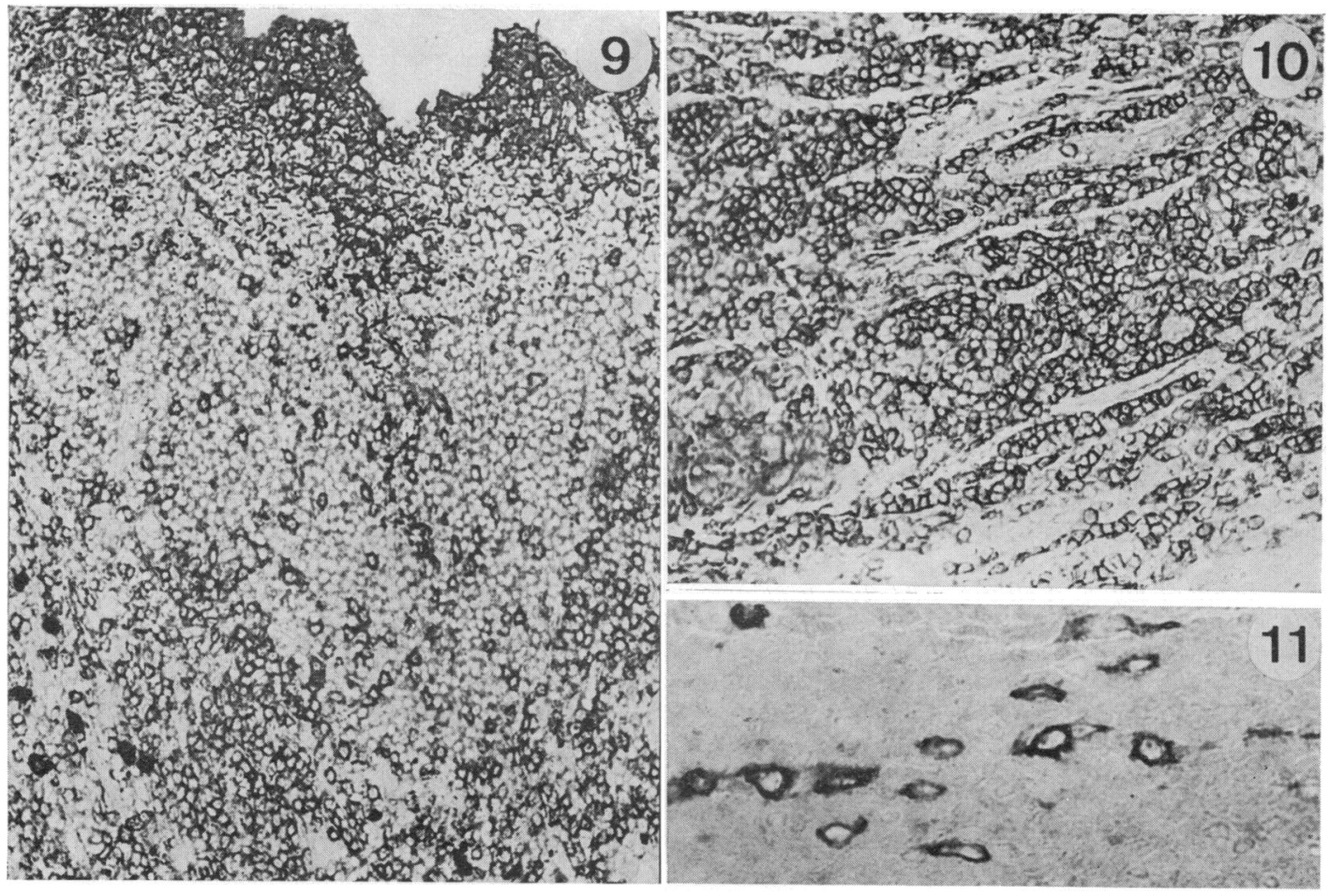

Fig. 9 Large ulcerative lesion in CD. Ulcer débris is shown at the top of the Figure. The majority of the inflammatory infiltrate consists of non-T cells. Below, clusters of T-cells are observed. IPT magnification, $\times \pm 150$.

Fig. 10 Heavy infiltration of the muscle coat and subserosa in CD by T-lymphocytes. IPT, $\times \pm 150$.

Fig. $11 T$-lymphocytes (spindle-shaped), penetrate between the individual muscle fibres in a patient with $C D$. IPT, $\times \pm 700$. 
No cytoplasmatic cell fluorescence was observed within the granuloma, except an occasional plasma cell.

\section{Ulcerative colitis}

The number of T-cells within the lamina propria of UC patients was normal or at the most slightly increased. As shown in Fig. 13 non-T cells (mainly plasma cells, identified in serial sections with haematoxylin and eosin staining), were the most prominent cell type in the mucosal inflammatory infiltrate. Increased numbers of T-lymphocytes were observed in the superficial layers of the submucosa, mainly surrounding lymphoid follicles. Although only limited numbers of surgical specimens of UC patients were studied, no extensive T-cell infiltrates in the deeper submucosa, muscle coat, or subserosal layer were encountered.

The Table summarises the results of semiquantitative estimations of $\mathrm{T}$-cell numbers in the various layers of the bowel wall. In contrast with controls and UC-sections, increased numbers of $\mathrm{T}$ - lymphocytes were found in the submucosa, muscle layer, and subserosa in a high proportion of the examined surgical specimens of CD patients. In rectal biopsies, however, where only the mucosal layer and superficial layers of the submucosa were present, no obvious differences were observed between the three groups.

\section{IMMUNOGLOBULIN-CONTAINING PLASMA}

CELLS

The average number of immunoglobulin-containing plasma cells per unit area of lamina propria is shown in Fig. 14. IgA-containing plasma cells predominated in all normal control sections and in most sections of UC patients. In $C D$, however, the number of IgA-containing plasma cells was considerably reduced, particularly obvious in areas showing characteristic transmural inflammatory pathology. Reduction of IgA-containing plasma cells appeared less important in normal areas or in sections showing non-specific inflammation. The number of IgMcontaining plasma cells was increased in $\mathrm{CD}$, where-

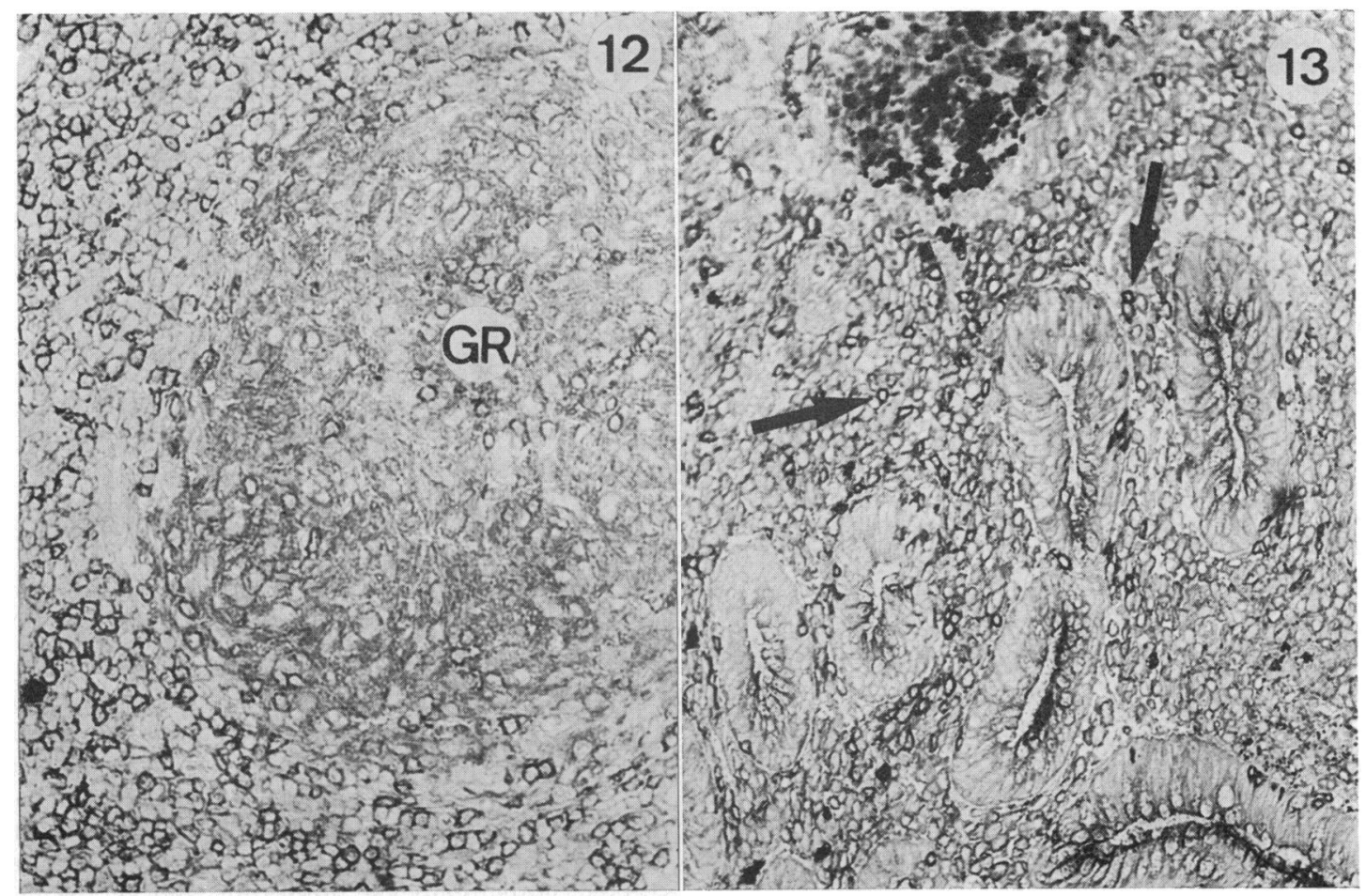

Fig. 12 Submucosal epitheloid cell granuloma $(G R)$ in $C D$, surrounded by large numbers of $T$ - and non- $T$ cells. IPT, $\times \pm 250$.

Fig. 13 Rectal mucosa of a patient with ulcerative colitis. Only occasionally, T-lymphocytes (arrows) are seen, amidst large numbers of non-T lymphocytes and plasma cells, the latter confirmed by HE staining and IFT. At the top of the figure a crypt abscess is seen. IPT, $\times \pm 150$. 
Table Semiquantitative score (score 0-4) of T-cell numbers in mucosa, submucosa, muscle layer and subserosa, expressed as percentage of total number of sections examined in control group $\left({ }^{*}\right)$, ulcerative colitis $(\dagger)$, and Crohn's disease ( $\left.\ddagger\right)$

\begin{tabular}{|c|c|c|c|c|c|c|c|c|c|c|}
\hline \multirow[b]{2}{*}{ Score } & \multicolumn{5}{|c|}{ Surgical specimens (\%) } & \multicolumn{5}{|c|}{ Rectal biopsies (\%) } \\
\hline & 0 & 1 & 2 & 3 & 4 & 0 & 1 & 2 & 3 & 4 \\
\hline \multicolumn{11}{|l|}{ Mucosa } \\
\hline$C^{*}$ & - & 10 & 90 & - & - & - & 14 & 86 & - & - \\
\hline $\mathrm{UC} \dagger$ & - & - & 83 & 17 & - & - & 7 & 86 & 7 & - \\
\hline $\mathrm{CD} \ddagger$ & - & 2 & 65 & 31 & 2 & - & 15 & 85 & - & - \\
\hline \multicolumn{11}{|l|}{ Submucosa } \\
\hline C & - & 90 & 10 & - & 一 & 一 & 71 & 29 & 一 & - \\
\hline UC & 一 & 14 & 72 & 14 & - & - & 43 & 57 & - & - \\
\hline CD & 一 & 20 & 22 & 44 & 14 & - & 61 & 31 & 8 & - \\
\hline \multicolumn{11}{|l|}{ Muscularis propria } \\
\hline C & - & 100 & - & - & - & & & & & \\
\hline UC & - & 43 & 57 & - & - & & & & & \\
\hline CD & - & 44 & 48 & 8 & - & & & & & \\
\hline \multicolumn{11}{|l|}{ Subserosa } \\
\hline C & 40 & 60 & - & - & - & & & & & \\
\hline UC & - & 80 & 20 & - & - & & & & & \\
\hline CD & - & 7 & 43 & 36 & 14 & & & & & \\
\hline Number of examined sections: & \multicolumn{3}{|c|}{$\begin{array}{l}\text { *Controls } \\
\text { †Ulcerative colitis } \\
\text { †Crohn's disease }\end{array}$} & \multicolumn{2}{|c|}{$\begin{array}{r}10 \text { ( } 5 \text { patients) } \\
8 \text { ( } 2 \text { patients) } \\
55 \text { (16 patients) }\end{array}$} & \multicolumn{2}{|c|}{$\begin{array}{l}\text { Controls } \\
\text { Ulcerative colitis } \\
\text { Crohn's disease }\end{array}$} & \multicolumn{3}{|c|}{$\begin{array}{r}7 \text { ( } 7 \text { patients) } \\
14 \text { (14 patients) } \\
13 \text { (13 patients) }\end{array}$} \\
\hline
\end{tabular}

The number of sections studied is shown at the bottom of the Table.

as IgG-containing plasma cell numbers were almost normal. In contrast with $\mathrm{CD}$, in active UC patients, high numbers of IgG-containing plasma cells were detected.

The ratio of IgA/IgM plasma cells varied considerably in all three groups, as shown in Fig. 15. Nevertheless, a significant reduction was observed in $\mathrm{CD}$, compared with controls $(P<0.001)$ and $U C$ patients $(P<0.001)$. No significant differences were noticed between the three groups, with respect to the $\operatorname{IgA} /$ IgG ratio.

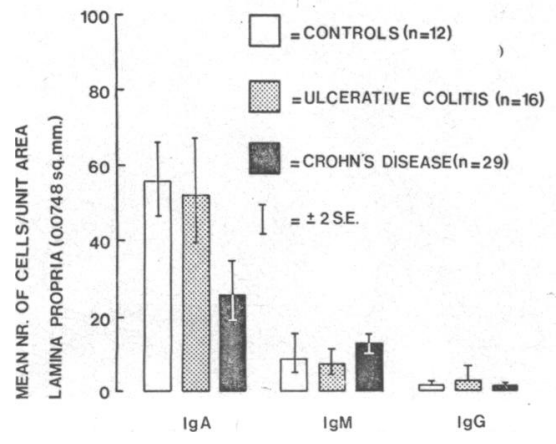

Fig. 14 Mean number of IgA-, IgM- and IgGcontaining plasma cells per unit area of lamina propria, of control subjects, $U C$ and $C D$ patients. The number refers to the number of patients studied in each group.

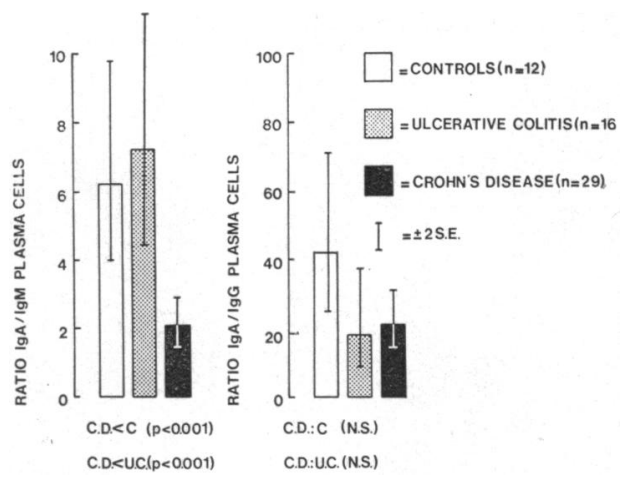

Fig. 15 Mean ratio of $\operatorname{Ig} A / \operatorname{Ig} M$ - and $\operatorname{Ig} A / \operatorname{Ig} G$ plasma cells of controls, $U C$ and $C D$ patients.

\section{Discussion}

In this study a detailed analysis has been made of the different lymphocyte subpopulations in tissue sections of patients with Crohn's disease, ulcerative colitis, and of control subjects, with the immunoperoxidase- and immunofluorescence technique. In contrast with Strickland et al. (1975), we used a specific antilymphocyte antiserum and a specific anti-T lymphocyte antiserum, facilitating in serial sections the comparison of the T-cell population with the total number of lymphocytes.

We have shown that, in $\mathrm{CD}$, T-cells are present in inflammatory infiltrates, particularly in the deeper 
layers of the bowel wall, while non-T lymphocytes predominate in the more superficial layers of the gut, in lymphoid follicles, and around areas of ulceration. The deep transmural penetration of T-cells, not observed in UC sections, and also the formation of granulomata, often surrounded by considerable numbers of T-cells, are arguments in favour of a chronic mainly T-cellular immune reaction, involving all bowel layers. This shift of 'responsive' $T$-cells towards the diseased gut possibly explains the reduction of peripheral blood T-cell numbers in CD (Strickland et al., 1974) and also the impaired anamnestic cellular immune response of peripheral blood lymphocytes (Meuwissen et al., 1975), which is likely to be a function of T-cells.

Why are T-lymphocytes so actively involved in CD? Can this shift of T-cells towards the diseased gut be explained by a defective immunoglobulinsynthesis, facilitating the passage of antigenic material? Immunoglobulin A indeed plays an important role in establishing a competent intestinal barrier (Shearman et al., 1972; Bienenstock et al., 1974). In our analysis we have observed a relative reduction of the number of IgA-containing plasma cells in the mucosal layer of CD patients, expressed as a ratio IgA/IgM. Brandtzaeg et al. (1976) have recently shown that an increase of the absolute number of IgA-containing cells in CD occurs, but less markedly in comparison with the increase of IgM- and IgG-containing cells; however, no obvious differences in IgA-cell numbers were found between CD or UC. In contrast, in our present study only CD patients showed often a striking reduction of IgAcontaining cells in the lamina propria, particularly in areas showing characteristic transmural inflammatory pathology. Similar observations of reduced $\operatorname{IgA}$ cell numbers in CD have been made by Persson and Danielsson (1973) and Green and Fox (1975). We feel, however, that no convincing arguments have yet been put forward to support the hypothesis that deficient local IgA secretion in CD is indeed of major pathogenetic importance. Serum IgA concentrations in CD are within normal levels (Bergman et al., 1973), and, to our knowledge, subjects with isolated IgA-deficiency have no increased risk of acquiring idiopathic inflammatory bowel disease, only very few case-histories being reported in the literature (Söltoft, 1972). Furthermore, reduction of IgAcontaining cells, with concomitant increase of IgMcontaining cells has also been described in other diseases, particularly coeliac disease (Douglas et al., 1970; Pettingale et al., 1971). Therefore the question remains, whether a deficient IgA-barrier, if present, is indeed a major pathogenetic factor in $\mathrm{CD}$, or, vice versa, whether the accentuated T-cellular reaction specifically affects local IgA synthesis(Lancet,1975).
In summary, our results indicate that a substantial proportion of the inflammatory infiltrate in $\mathrm{CD}$ consists of T-lymphocytes. Our findings are in agreement with Strickland's data (1975) and are also supported by the experimental work of Clancy (1976), who showed that human gut mucosal lymphocytes of $\mathrm{CD}$ patients in vitro culture behave to a considerable extent as $\mathrm{T}$-lymphocytes. The significance, however, of this chronic T-cellular immune reaction in CD remains to be elucidated and therefore further analysis of the morphology and function of $\mathrm{T}$ lymphocytes and T-lymphocyte subpopulations is required in order to define more accurately cellular immune phenomena in CD. Finally, attention should also be paid to the exact identification of the socalled cytotoxic lymphocytes or K-cells, which may also play an important role in inflammatory bowel disease, as suggested by Strickland et al. (1975), Stobo and Shorter (1976), and by our own preliminary findings (Meuwissen et al., 1976, b).

We are grateful to Miss Cecile M. J. van Loon, Miss Gerda van Loo, Miss Suze Krieg, and Mr C. Harteloh for their technical assistance. The statistical analysis was performed by Mr M. F. M. Janssen.

\section{References}

Avrameas, S., and Ternynck, T. (1971). Peroxidase labelled antibody and Fab conjugates with enhanced intracellular penetration. Immunochemistry, 8, 1175-1179.

Bergman, L., Johansson, S. G. O., and Krause, U. (1973). The immunoglobulin concentrations in serum and bowe secretions in patients with Crohn's disease. Scandinavian Journal of Gastroenterology, 8, 401-406.

Bienenstock, J. (1974). The physiology of the local immune response and the gastrointestinal tract. In Progress in Immunology, vol. 4, pp. 197-207. Edited by L. Brent and J. Holborow, North-Holland: Amsterdam.

Brandtzaeg, P., and Baklien, K. (1976). Immunohistochemical studies of the formation and epithelial transport of immunoglobulins in normal and diseased human intestinal mucosa. Scandinavian Journal of Gastroenterology, 11, suppl. 36, 1-45.

Brutel de la Rivière, A., Verhoef-Karssen, Paula R., Bosma, A., v.d. Borne, A. E. G. Kr., and Engelfriet, C. P. (1976a). The preparation of specific antisera against human blood cells, applicable in the indirect immunofluorescence technique. Scandinavian Journal of Immunology. (In press.)

Brutel de la Rivière, A., Verhoef-Karssen, Paula R., van Oers, M. H. J., Schoorl, R., Feltkamp-Vroom, Thea M., v.d. Borne, A. E. G. Kr., and Zeylemaker, W. P. (1976b). The preparation and specificity testing of a rabbit antihuman thymocyte serum. Vox Sanguinis (In press.)

Clancy, R. (1976). Isolation and kinetic characteristics of mucosal lymphocytes in Crohn's disease. Gastroenterology, 70, 177-180.

Coons, A. H., Leduc, E. H., and Connolly, J. M. (1955). Studies on antibody production. I. A method for the histochemical demonstration of specific antibody and its application to a study of the hyperimmune rabbit. Journal of Experimental Medicine, 102, 49-60.

Douglas, A. P., Crabbé, P. A., and Hobbs, J. R. (1970). Immunochemical studies of the serum, intestinal secretions 
and intestinal mucosa in patients with adult celiac disease and other forms of the celiac syndrome. Gastroenterology, 59, 414-425.

Feltkamp-Vroom, Thea M., and Boode, J. H. M. (1970). An embedding and sectioning technique for immunohistochemical studies of minute specimens of tissue. Journal of Clinical Pathology, 23, 188-189.

Green, F. H. Y., and Fox, H. (1975). The distribution of mucosal antibodies in the bowel of patients with Crohn's disease. Gut, 16, 125-131.

Guillou, P. J., Brennan, T. G., and Giles, G. R. (1973) Lymphocyte transformation in the mesenteric lymph nodes of patients with Crohn's disease. Gut, 14, 20-24.

Jones, J. V., Housley, J., Ashurst, P. M., and Hawkins, C. F. (1969). Development of delayed hypersensitivity to dinitrochlorobenzene in patients with Crohn's disease. Gut, 10, $52-56$.

Lancet (1975). Selective IgA deficiency. Leading article. Lancet, 2, 1291-1292.

Meuwissen, S. G. M., Pape, K. S. S. B., Agenant, D., Oushoorn, H. H., and Tytgat, G. N. J. (1976a). Crohn's disease of the colon. American Journal of Digestive Diseases, 21, 81-89.

Meuwissen, S. G. M., Feltkamp-Vroom, Thea M., Zeylemaker, W. P., Schellekens, P. Th. A., Brutel de la Rivière, A., and Tytgat, G. N. (1976b). Crohn's disease, clinical activity and cellular immunity. In Proceedings of the Workshop on Crohn's Disease, Leyden, 23-25 Oct. 1975. pp. 121-127. Excerpta Medica: Amsterdam.

Meuwissen, S. G. M., Schellekens, P. T. A., Huismans, L., and Tytgat, G. N. (1975). Impaired anamnestic cellular immune response in patients with Crohn's disease. Gut, 16, 854-860.

Morson, B. C., and Dawson, I. M. P. (1972). Gastrointestinal Pathology, pp. 269-274. Blackwell: Oxford.

Parent, K., Barrett, J., and Wilson, I. D. (1971). Investigation of the pathogenic mechanisms in regional enteritis with in vitro lymphocyte cultures. Gastroenterology, 61, 431439.

Persson, S., and Danielsson, D. (1973). Studies on Crohn's disease. II. Immunoglobulin-containing cells in the terminal ileum. Acta Chirurgica Scandinavica, 139, 735-738.

Pettingale, K. W. (1971). Immunoglobulin-containing cells in the coeliac syndrome. Gut, 12, 291-296.

Richens, E. R., Williams, M. J., Gough, K. K., and Ancill, R. J. (1974). Mixed-lymphocyte reaction as a measure of immunological competence of lymphocytes from patients with Crohn's disease. Gut, 15, 24-28.

Sachar, D. B., Taub, R. N., Brown, S. M., Present, D. H., Korelitz, B. I., and Janowitz, H. D. (1973). Impaired lymphocyte responsiveness in inflammatory bowel disease. Gastroenterology, 64, 203-209.

Schoorl, R., Brutel de la Rivière, A., v.d. Borne, A. E. G. Kr., and Feltkamp-Vroom, Thea M. (1976). Identification of Tand B-lymphocytes in human breast cancer with the immunofluorescence technique. American Journal of Pathology. (In press.)

Shearman, D. J. C., Parkin, D. M., and McClelland, D. B. L. (1972). The demonstration and function of antibodies in the gastrointestinal tract. Gut, 13, 483-499.

Söltoft, J., Petersen, L., and Kruse, P. (1972). Immunoglobulin deficiency and regional enteritis. Scandinavian Journal of Gastroenterology, 7, 233-236.

Stobo, J. D., Tomasi, T. B., Huizenga, K. A., Spencer, R. J., and Shorter, R. G. (1976). In vitro studies of inflammatory bowel disease. Surface receptors of the mononuclear cell required to lyse allogeneic colonic epithelial cells. Gastroenterology, 70, 171-177.

Strickland, R. G., Husby, G., Black, W. C., and Williams, R. C., Jr. (1975). Peripheral blood and intestinal lymphocyte sub-populations in Crohn's disease. Gut, 16, 847-853.

Strickland, R. G., Korsmeyer, S., Soltis, R. D., Wilson, I. D., and Williams, R. C., Jr (1974). Peripheral blood T and B cells in chronic inflammatory bowel disease. Gastroenterology, 67, 569-577.

Whitehead, R. (1973). Mucosal Biopsy of the Gastrointestinal Tract, pp. 139-166. Saunders: London.

WHO/IARC (1974). Report of a WHO/IARC-sponsored Workshop on human B and T cells, London, 15-17 July 1974. Scandinavian Journal of Immunology, 3, 521-532.

Williams, W. J. (1965). A study of Crohn's syndrome using tissue extracts and the Kveim and Mantoux tests. Gut, 6, 503-505.

Yam, L. T., Li, C. Y., and Crosby, W. H. (1971). Cytochemical identification of monocytes and granulocytes. American Journal of Clinical Pathology, 55, 283-290. 